\title{
PENDIRIAN BANK UMUM DAN BPR KONVENSIONAL ATAU SYARIAH
}

\section{ESTABLISHMENT OF COMMERCIAL BANKS AND CONVENTIONAL OR SHARIA BPR}

\author{
Nurul Ichsan Hasan1a \\ 1aUniversitas Islam Negeri Syarif Hidayatullah Jakarta, Jl. Ir. H. Djuanda No. 95, Ciputat, \\ Cempaka Putih, Ciputat Timur, Kota Tangerang Selatan, Banten 15412, E-mail: \\ nurul.ichsan@uinjkt.ac.id
}

\begin{abstract}
This article regarding the procedures for the establishment of a Commercial Bank and Rural Bank both of which can be set up and run their business license from Bank Indonesia as the Central Bank. Granting permission to set up commercial banks conducted through two stages. First, the stage of approval to conduct preparations for establishment of the bank concerned. The second stage of the business license for the provision of a license to conduct business after the preparation completed. During yet received an operating license, the parties received approval in principle not allowed to conduct any business activity in the banking sector. Rural Banks also can be upgraded to a commercial bank with prevailing regulations and adequate capabilities.
\end{abstract}

Keyword: Bank, BPR, Establishment License

\begin{abstract}
ABSTRAK
Tulisan ini berkenaan dengan tatacara pendirian Bank Umum dan Bank Perkreditan Rakyat dimana keduanya dapat didirikan dan menjalankan usahanya dengan izin dari Bank Indonesia selaku Bank Sentral. Pemberian izin untuk mendirikan Bank Umum dilakukan melalui 2 tahapan. Pertama, tahap persetujuan untuk melakukan persiapan pendirian bank yang bersangkutan. Tahap kedua berupa pemberian izin usaha yakni izin yang diberikan untuk melakukan kegiatan usaha setelah persiapan selesai dilakukan. Selama belum mendapat izin usaha, pihak yang mendapat persetujuan prinsip tidak diperkenankan untuk melakukan kegiatan usaha apapun di bidang perbankan. Bank Perkreditan Rakyat juga dapat ditingkatkan statusnya menjadi Bank Umum dengan ketentuan yang berlaku dan kemampuan yang memadai.
\end{abstract}

Kata Kunci: Bank, BPR, Izin Pendirian

Nurul Ichsan. 2018. Pendirian Bank Umum dan BPR Konvensional atau Syariah. Jurnal Nisbah 4 (1): 34-50 


\section{PENDAHULUAN}

Bank merupakan lembaga perantara keuangan yang seharusnya mampu melakukan mekanisme pengumpulan dana secara seimbang dan benar sesuai dengan ketentuan yang berlaku, oleh karena itu maka perlu ada kejelasan akan hukum dan badan hukum sistem operasional perbankan serta izin pendirian bank.

Munculnya banyak lembaga keuangan yang ada di Indonesia dewasa ini memang menuntut peran pemerintah dan pejabat yang berwenang untuk membuat peraturan dan undang-undang izin pendirian bank agar bank dapat lebih bermanfaat bagi semua orang. Dengan demikian berbagai jenis bank yang muncul di Indonesia dan haruslah sesuai dengan ketentuan yang ditetapkan oleh pejabat yang berwenang bukan hanya untuk kepentingan bisnis semata.

Adapun syarat dan ketentuan yang ditetapkan oleh pemerintah dan pejabat yang berwenang lewat pasal-pasal dalam undang undang adalah untuk mencapai tujuan yang lebih baik jika bank tersebut mengalami masalah dan menghadapi pasar. Agar bank tersebut dapat berfungsi sebagai suatu lembaga intermediasi yaitu lembaga yang mengarahkan dana dari masyarakat dan menyalurkan kembali ke masyarakat yang membutuhkan untuk meningkatkan taraf hidup masyarakat dengan denikian dapat terwujud. Bedasarkan latar belakang diatas maka perlu dipaparkan lebih mendalam tentang prosedur dan syarat pendirian bank.

\section{PEMBAHASAN}

Bank sebagai suatu badan usaha yang mempunyai kegiatan usaha menghimpun dana dari masyarakat dalam berbagai bentuknya, sudah tentu membutuhkan banyak persyaratan dalam melaksanakan kegiatan usahanya. Ini sangat penting untuk melindungi kepentingan masyarakat itu sendiri, terutama terhadap nasabah penyimpan dan simpanannya. Menurut jenis usahanya bank terdiri dari Bank Umum dan BPR, hal ini terdapat pada Pasal 5 ayat (1) Undang-Undang Republik Indonesia Nomor 7 Tahun 1992 Tentang Perbankan Sebagaimana telah diubah dengan Undang-Undang Nomor 10 Tahun 1998.

Sesuai dengan ketentuan mengenai izin pendirian bank maka setiap orang atau badan hukum yang berkinginan untuk mendirikan bank wajiblah mengambil dasar hukum dan ketentuan yang ada dari Pasal 16 Undang-Undang Nomor 10 Tahun 1998 baik ayat 1, 2 dan 3 yang berbunyi antara lain ayat 1 :

Setiap pihak yang melakukan kegiatan menghimpun dana dari masyarakat dalam bentuk simpanan wajib terlebih dahulu memperoleh izin usaha sebagai Bank Umum atau Bank Perkreditan Rakyat dari Pimpinan Bank Indonesia, kecuali apabila kegiatan menghimpun dana dari masyarakat dimaksud diatur dengan Undang-undang tersendiri.

Dalam ketentuan pasal 16 ayat 1 di atas mengandung arti bahwa kegiatan menghimpun dana dari masyarakat oleh siapapun pada dasarnya merupakan kegiatan yang perlu diawasi, mengingat dalam kegiatan itu terkait kepentingan masyarakat yang dananya disimpan pada pihak yang menghimpun dana tersebut. Sehubungan dengan itu dalam ayat ini ditegaskan bahwa kegiatan menghimpun dana dari masyarakat dalam bentuk simpanan hanya dapat dilakukan oleh pihak yang telah memperoleh izin usaha sebagai Bank Umum atau sebagai Bank Perkreditan Rakyat. 
Namun, di masyarakat terdapat pula jenis lembaga lainnya yang juga melakukan kegiatan penghimpunan dana masyarakat dalam bentuk simpanan atau semacam simpanan, misalnya yang dilakukan oleh kantor pos, oleh dana pensiun, atau oleh perusahaan asuransi. Kegiatan lembagalembaga tersebut tidak dicakup dalam kegiatan usaha perbankan berdasarkan ketentuan ayat ini. Kegiatan penghimpunan dana dari masyarakat yang dilakukan oleh lembaga-lembaga tersebut diatur dengan undang-undang tersendiri.

Dalam Pasal 16 ayat 2 selanjutnya yang berbunyi:

Untuk memperoleh izin usaha Bank Umum dan Bank Perkreditan Rakyat sebagaimana dimaksud dalam ayat (1), wajib dipenuhi persyaratan sekurangkurangnya tentang:

\section{Susunan Organisasi Dan}

\section{Kepengurusan ;}

2. Permodalan;

3. Kepemilikan;

4. Keahlian di bidang Perbankan;

5. Kelayakan rencana kerja.

Dari ketentuan pasal 16 ayat 2 tersebut dapat dikemukakan bahwa dalam hal memberikan izin usaha sebagai bank umum dan bank perkreditan rakyat, bank Indonesia selain memerhatikan pemenuhan persyaratan sebagaimana dimaksud dalam ayat ini, juga wajib memerhatikan tingkat persaingan yang sehat antar bank, tingkat kejenuhan jumlah bank dalam suatu wilayah tertentu, serta pemerataan pembangunan ekonomi nasional.

Sedangkan dalam pasal 16 ayat 3 yang berbunyi:

Persyaratan dan tata cara perizinan bank sebagaimana dimaksud dalam ayat (2) ditetapkan oleh Bank Indonesia

Sebagaimana halnya ketentuan pasal 16 ayat 1 dan ayat 2, maka berhubungan dengan ketentuan pasal 16 ayat 3 dapat dikemukakan bahwa pokok-pokok ketentuan yang ditetapkan oleh Bank Indonesia memuat antara lain adalah:

1. Persyaratan untuk menjadi pengurus bank antara lain menyangkut keahlian di bidang perbankan dan konduite yang lain

2. Larangan adanya hubungan keluarga diantara pengurus bank.

3. Modal disetor minimum untuk pendirian Bank Umum dan Bank Perkreditan Rakyat.

4. Batas maksimum kepemilikan dan kepengurusan.

5. Kelayakan rencana kerja.

6. Batas waktu pemberian izin pendirian bank.

Dari ketentuan hukum di atas dapat dilihat bahwa langkah pertama yang harus dilakukan dalam pendirian bank adalah menentukan jenis bank yang akan didirikan, apakah Bank Umum atau Bank Perkreditan Rakyat. Dari kedua jenis bank, terdapat beberapa perbedaan mengenai syaratsyarat yang harus dipenuhi untuk mendirikan sebuah bank. Penjelasan kedua bank tersebut akan dijabarkan sebagaimana berikut dibawah ini.

\section{Pendirian Bank Umum}

Bank Umum disebut juga sebagai "bank dagang", "bank komersial", "bank kredit", bahkan di beberapa Negara disebut sebagai "bank deposito". Bank yang melaksanakan kegiatan usaha secara konvensional dan/atau berdasarkan prinsip syariah ini dalam kegiatannya memberikan jasa-jasa dalam lalu lintas pembayaran.Sebagai Bank konvensional, Bank Umum melakukan usaha perbankan dengan memberikan kredit kepada nasabah baik perorangan maupun perusahaan. Sedangkan Bank Umum yang menganut prinsip syariah menggunakan aturan perjanjian berdasarkan Hukum Islam antara bank dengan pihak lain untuk 
menyimpan dana dan/atau pembiayaan kegiatan usaha, atau kegiatan lainnya yang dinyatakan sesuai dengan syariah.

Bank Umum ini sendiri dapat berupa Bank Milik Negara, Swasta, maupun Koperasi, yang dalam pengumpulan dananya terutama menerima simpanan dalam bentuk giro, deposito, serta tabungan dan dalam usahanya terutama memberikan kredit jangka pendek. Kredit jangka pendek ini dipilih karena dana utama yang diterima juga berjangka waktu pendek, sehingga pemberian kredit jangka pendek diharapkan tidak mengganggu kemampuan bank untuk memenuhi jangka pendeknya. Suatu bank dikatakan sebagai Bank Umum karena bank tersebut mendapatkan keuntungan dari selisih bunga yang diterima dari peminjam dengan yang dibayarkan oleh bank kepada depositor (disebut spread).

Sedangkan BPR adalah bank yang melaksanakan kegiatan usaha secara konvensional atau berdasarkan prinsip syariah ini dalam kegiatannya tidak memberikan jasa dalam lalu lintas pembayaran. Jadi disini, terlihat bahwa perbedaan antara bank umum dengan BPR terletak dalam kegiatan pemberian jasa dalam lalu lintas pembayaran. Bank Perkreditan Rakyat memberikan jasa berupa menerima simpanan hanya dalam bentuk deposito berjangka, tabungan, dan atau bentuk lainnya yang dipersamakan dengan itu.

Bank Umum dapat didirikan dan menjalankan usahanya dengan izin Bank Indonesia selaku Bank Sentral. Pemberian izin untuk mendirikan Bank Umum dilakukan melalui 2 tahapan. Pertama, tahap persetujuan untuk melakukan persiapan pendirian bank yang bersangkutan. Tahap kedua berupa pemberian izin usaha yakni izin yang diberikan untuk melakukan kegiatan usaha setelah persiapan selesai dilakukan. Selama belum mendapat izin usaha, pihak yang mendapat persetujuan prinsip tidak diperkenankan untuk melakukan kegiatan usaha apapun di bidang perbankan.

a. Syarat Umum, Modal Disetor dan Persetujuan Prinsip

1. Syarat Umum

Penjelasan secara rinci untuk syarat pendirian bank umum dijabarkan dalam SK Direksi BI No: 32/33/Kep/Dir, Tentang Bank Umum tanggal 12 Mei 1999, dalam pasal 3 disebutkan :

a) Bank hanya dapat didirikan dan melakukan kegiatan usaha dengan izin Direksi Bank Indonesia.

b) Bank hanya dapat didirikan oleh:

c) WNI dan/atau Badan Hukum Indonesia; atau

d) WNI dan/atau Badan Hukum Indonesia dengan WNA dan/atau Badan Hukum Asing secara kemitraan.

2. Modal yang selanjutnya dalam pasal 4 disebutkan:

a) Modal disetor untuk mendirikan Bank ditetapkan sekurang-kurangnya sebesar Rp 3.000.000.000,00 (tiga triliun rupiah);

b) Modal disetor bagi Bank yang berbentuk hukum Koperasi adalah simpanan pokok, simpanan wajib, dan hibah sebagaimana diatur dalam undang-undang tentang Perkoperasian;

c) Modal disetor yang berasal dari warga Negara asing dan/atau badan hukum asing, sebagaimana dimaksud dalam Pasal 3 angka (2) huruf b setinggi-tingginya sebesar $99 \%$ (Sembilan puluh sembilah persen) dari modal disetor bank.

3. Persetujuan Prinsip

Sebagaimana dijabarkan dalam pasal 6 yaitu permohonan untuk mendapatkan persetujuan prinsip sebagaimana dimaksud dalam Pasal 5 huruf a diajukan sekurang-kurangnya oleh seorang calon pemilik kepada 
direksi Bank Indonesia sesuai dengan format dalam Lampiran I dan wajib dilampiri dengan:

1) Rancangan akta pendirian badan hukum, termasuk rancangan anggaran dasar yang sekurangkurangnya memuat:

a) Nama dan tempat kedudukan;

b) Kegiatan usaha sebagai Bank;

c) Permodalan;

d) Kepemilikan;

e) Wewenang, tanggung jawab, dan masa jabatan dewan Komisaris serta Direksi;

2) Data kepemilikan berupa:

a) Daftar calon pemegang saham berikut rincian besarnya masingmasing kepemilikan saham bagi Bank yang berbentuk hukum Perseroan Terbatas/Perusahaan Daerah;

b) Daftar calon anggota berikut rincian jumlah simpanan pokok dan simpanan wajib, serta daftar hibah bagi Bank yang berbentuk hukum Koperasi;

3) Daftar calon anggota dewan Komisaris dan anggota Direksi disertai dengan:

a) Fotokopi tanda pengenal yang dapat berupa Kartu Tanda Penduduk (KTP) atau paspor;

b) Riwayat hidup;

c) Surat penyertaan pribadi (personal statement)yang menyatakan tidak pernah melakukan tindakan tercela di bidang perbankan, keuangan, dan usaha lainnya dan atau tidak pernah dihukum karena terbukti melakukan tindak pidana kejahatan;

d) Surat keterangan atau bukti tertulis dari bank tempat bekerja sebelumnya mengenai pengalaman operasional di bidang perbankan bagi calon Direksi yang telah berpengalaman; dan e) Surat keterangan dari lembaga pendidikan mengenai pendidikan perbankan yang pernah diikuti dan/atau bukti tertulis bagi Bank tempat bekerja sebelumnya mengenai pengalaman di bidang perbankan bagi calon anggota Dewan Komisaris.

4) Rencana susunan organisasi;

5) Rencana kerja untuk tahun pertama yang sekurang-kurangnya memuat:

a) Hasil penelaahan mengenai peluang pasar dan potensi ekonomi;

b) Rencana kegiatan usaha yang mencakup penghimpunan dan penyaluran dana serta langkahlangkah kegiatan yang akan dilakukan dalam mewujudkan rencana yang dimaksud.

6) Bukti setoran modal sekurangkurangnya 30\% (tiga puluh persen) dari modal yang disetor sebagaimana dimaksud dalam Pasal 4 ayat (1), dalam bentuk fotokopi bilyet deposito pada Bank di Indonesia dan atas nama "Direksi Bank Indonesia q.q. salah seorang calon pemilik untuk pendirian Bank yang yang bersangkutan" dengan mencantumkan keterangan bahwa pencairannya hanya dapat dilakukan setelah mendapat persetujuan tertulis dari Direksi Bank Indonesia;

7) Surat pernyataan dari calon pemegang saham dan Bank yang berbentuk hukum Perseroan Terbatas/Perusahaan Daerah atau dari calon anggota bagi Bank yang berbentuk hukum Koperasi, bahwa setoran modal sebagaimana yang dimaksud dalam huruf f:

- Tidak berasal dari pinjaman atau fasilitas pembiayaan dalam bentuk apapun dari bank dan/atau pihak lain di Indonesia; 
- Tidak berasal dari dan untuk tujuan pencucian uang (money laundering).

b. Daftar Calon Pemegang Saham Atau Daftar Calon Anggota

Sebagaimana dimaksud dalam pasal 1 huruf $b$ :

1. Dalam hal perorangan wajib dilampiri dengan dokumen sebagaimana yang dimaksud dalam ayat (1) huruf c angka 1 sampai dengan angka 3

2. Dalam hal badan hukum wajib dilampiri dengan:

a) Akta pendirian badan hukum, termasuk anggaran dasar berikut perubahan-perubahan yang telah mendapat pengesahan dari instansi berwenang termasuk bagi badan hukum asing sesuai dengan ketentuan yang berlaku di negara asal badan hukum tersebut;

b) Dokumen sebagaimana dimaksud dalam ayat (1) huruf c angka 1 sampai dengan angka 3 dari seluruh dewan komisaris dan direksi dari badan hukum yang bersangkutan;

c) Rekomendasi dari instansi berwenang di Negara asal bagi bbadan hukum asing;

d) Daftar pemegang ssaham berikut rincian besarnya masing-masing kepemilikan saham bagi baddan hukum Perseroan

Terbatas/Perusahaan Daerah, atau daftar anggota berikut rincian jumlah simpanan pokok dan simpanan wajib, serta daftar hibah bagi badan hukum koperasi;

e) Laporan keuangan badan hukum yang diaudit oleh akuntan public dengan posisi paling lama 6 (enam) bulan sebelum tanggal pengajuan

\author{
permohonan \\ prinsip. \\ f) Data Kepemilikan Bank.
}

c. Izin Usaha

Dalam mendirikan sebuah bank tidak hanya dilihat dari jumlah modal yang dimilikinya, akan tetapi siapa pemilik dan pengelola bank. Prosedur tersebut tampak pada ketentuan Pasal 9: Permohonan untuk mendapat ijin usaha sebagaimana dimaksud dalam pasal 5 huruf b diajukan oleh Direksi Bank kepada Direksi Bank Indonesia sesuai dengan format pada lampiran 2 dan wajib dilampiri dengan:

1. Akta pendirian badan hukum, termasuk anggaran dasar badan hukumyang telah disahkan oleh instansi yang berwenang

2. Data kepemilikan berupa:

a) Daftar pemegang saham berikut rincian besarnya kepemilikan saham bagi bank yang berbentuk hukum Perseroan Terbatas/Perusahaan Daerah; atau

b) Daftar anggota berikut rincian jumlah simpanan pokok dan simpanan wajib serta daftar hibah bagi Bank yang berbentuk hukum Koperasi; yang masingmasing disertai dengan dokumen sebagaimana dimaksud dalam pasal 6 ayat (2);

3. Daftar susunan dewan Komisaris dan Direksi, disertai dengan:

a) Pas foto terakhir ukuran $4 \times 6$ $\mathrm{cm}$;

b) contoh tandatangan dan paraf;

c) dokumen sebagaimana dimaksud dalam Pasal 6 ayat (1) huruf c;

d) fotokopi Kartu Izin Menetap Sementara (KIMS) dan fotokopi surat izin bekerja dari instansi berwenang, bagi warga Negara asing;

4. Susunan organisasi serta system dan prosedur kerja, termasuk susunan personalia; 
5. Bukti pelunasan modal disetor sebagaimana dimaksud dalam Pasal 4 ayat (1), dalam bentuk fotokopi bilyet deposito pada Bank di Indonesia atas nama "Direksi Bank Indonesia q.q. salah seorang pemilik Bank yang bersangkutan" dengan mencantumkan keterangan bahwa pencairannya hanya dapat dilakukan setelah mendapat persetujuan tertulis dari Direksi Bank Indonesia.

6. bukti kesiapan operasional berupa:
a) daftar aktiva tetap dan inventaris;
b) bukti penguasaan gedung berupa bukti kepemilikan atau perjanjian sewa-menyewa gedung kantor;
c) foto gedung kantor dan tata letak ruangan;
d) contoh formulir/warkat yang akan digunakan untuk operasional Bank;
e) Nomor Pokok Wajib Pajak (NPWP) dan Tanda Daftar Perusahaan (TDP);

7. Surat pernyataan dari pemegang saham bagi Bank yang berbentuk hukum Perseroan Terbatas Perusahaan Daerah atau dari anggota bagi Bank yang berbentuk hukum Koperasi bunga pelunasan modal disetor sebagaimana dimaksud dalam huruf c:

a) tidak bersal dari pinjaman atau fasilitas pembiayaan dalam bentuk apapun dari Bank dan/atau pihak lain di Indonesia;

b) tidak berasal dari dan untuk tujuan pencucian uang (money loundering);

8. Surat pernyataan tidak merangkap jabatan melebihi ketentuan sebagaimana dimaksud dalam Pasal 21 ayat (3) bagi anggota dewan Komisaris;

9. Surat pernyataan tidak merangkap jabatan sebagaimana dimaksud dalam Pasal 23 ayat (2) bagi anggota Direksi;

10. Surat pernyataan dari anggota dewan Komisaris bahwa yang bersangkutan tidak mempunyai hubungan keluarga sebagaimana dimaksud dalam Pasal 21 ayat (4);

11. Surat pernyataan dari anggota Direksi bahwa yang bersangkutan tidak mempunyai hubungan keluarga sebagaimana dimaksud dalam Pasal 23 ayat (1);

12. Surat pernyataan dari anggota Direksi bahwa yang bersangkutan baik secara sendiri-sendiri maupun bersama-sama tidak memiliki saham melebihi $25 \%$ dari modal disetor pada suatu perusahaan lain sebagaimana dimaksud dalam Pasal 23 ayat (3).

Selanjutnya dalam Pasal 13 disebutkan: Kepemilikan Bank oleh Badan Hukum sebagaimana dimaksud dalam Pasal 3 ayat (2) setinggitingginya sebesar modal sendiri bersih badan hukum yang bersangkutan. Modal sendiri bersih sebagaimana dimaksud dalam ayat (1) merupakan:

1. Penjumlahan dari modal disetor, cadangan, dan laba dikurangi penyertaan dan kerugian, bagi badan hukum Perseroan Terbatas/Perusahaan Daerah; atau

2. Penjumlahan dari simpanan pokok, simpanan wajib, hibah, modal penyertaan, dana cadangan dan Sisa Hasil Usaha dikurangi penyertaan dan kerugian bagi Badan Hukum Koperasi.

d. Yang dapat menjadi Pemilik Bank

Dalam Pasal 15 dijabarkan siapa saja yang dapat menjadi pemilik bank adalah pihak-pihak yang:

1. Tidak termasuk dalam daftar orang tercela di bidang perbankan sesuai dengan yang ditetapkan oleh Bank Indonesia;

2. Menurut penilaian Bank Indonesia yang bersangkutan memiliki 
integritas yang baik. Pemilik Bank yang memiliki integritas yang baik sebagaimana dimaksud dalam ayat (1) huruf b, antara lain adalah pihakpihak yang:

a) Memiliki akhlak dan moral yang baik;

b) Mematuhi peraturan perundangundangan yang berlaku;

c) Memiliki komitmen yang tinggi terhadap perkembangan operasional bank yang sehat;

d) Dinilai layak dan wajar untuk menjadi pemegang saham Bank.

e. Perubahan Modal dan Perubahan Pemilik

1. Perubahan Modal

Dalam Pasal 10 disebutkan:

Perubahan modal dasar bagi Bank yang berbentuk Hukum Perseroan Terbatas/Perusahaan Daerah wajib dilaporkan oleh Direksi Bank kepada bank Indonesia selambat-lambatnya 10 hari setelah tanggal persetujuan perubahan anggaran dasar dari instansi yang berwenang dilampiri dengan:

a) Notulen rapat umum pemegang saham;

b) Perubahan anggaran dasar yang telah disetujui oleh instansi yang berwenang.

Perubahan modal bagi Bank yang berbentuk Badan Hukum Koperasi, wajib dilaporkan oleh Direksi Bank kepada bank Indonesia selambatlambatnya 10 hari setelah tanggal perubahan anggaran dasar dilampiri dengan:

a) Notulen rapat anggota;

b) Perubahan anggaran dasar yang telah disetujui oleh rapat anggota.

2. Perubahan Pemilik Dalam Pasal 18 disebutkan:

- Perubahan komposisi kepemilikan yang tidak mengakibatkan penggantian dan/atau penambahan pemilik Bank, wajib dilaporkan oleh Direksi Bank kepada Bank
Indonesia selambat-lambatnya 10 hari setelah perubahan dilakukan.

- Laporan perubahan komposisi kepemilikan sebagaimana dimaksud dalam ayat (1) yang diakibatkan adanya penambahan modal disetor wajib dilampiri dengan:

a) Bukti penyetoran;

b) Notulen rapat umum pemegang saham/rapat anggota.

c) Surat pernyataan dari pemegang saham sebagaimana dimaksud dalam Pasal 9 huruf b;

d) Data kepemilikan sebagaimana dimaksud dalam Pasal 9 huruf b.

- Laporan perubahan komposisi kepemilikan sebagaimana dimaksud dalam ayat (1) yang tidak mengubah modal disetor wajib dilampiri dengan dokumen sebagaimana dimaksud dalam ayat (2) huruf b,c dan d.

\section{f. Dewan Komisaris}

Yang dapat menjadi anggota komisaris bank diatur dalam Pasal 19, yaitu:

1. Anggota dewan Komisaris dan Direksi wajib memenuhi persyaratan sebagai berikut:

a) Tidak termasuk dalam daftar orang tercela dibidang perbankan sesuai dengan yang ditetapkan oleh Bank Indonesia;

b) Memiliki kemampuan dalam menjalankan tugasnya;

c) Menurut penilaian Bank Indonesia yang bersangkutan memiliki integritas yang baik..Anggota dewan komisaris dan Direksi yang memiliki integritas yang baik sebagaimana dimaksud dalam ayat (1) huruf c, antara lain adalah pihak-pihak yang:

1) Memiliki akhlak dan moral yang baik;

2) Mematuhi peraturan perundang-undangan yang berlaku; 
3) Memiliki komitmen yang tinggi terhadap pengembangan operasional Bank yang sehat;

4) Dinilai layak dan wajar untuk menjadi anggota dewan Komisaris dan Direksi Bank.

2. Dalam Pasal 20:

* Bank yang sebagian sahamnya dimiliki oleh pihak asing dapat menempatkan Warga Negara Asing sebagai anggota Dewan Komisaris dan Direksi.

* Di antara Dewan Komisaris dan Direksi Bank sebagaimana dimaksud dalam ayat (1), sekurangkurangnya terdapat satu orang anggota dewan Komisaris dan satu orang anggota Direksi berkewarganegaraan Indonesia.

3. Dalam Pasal 21:

* Jumlah anggota dewan Komisaris sekurang-kurangnya dua orang.

* Anggota dewan Komisaris sebagaimana dimaksud dalam ayat (1) wajib memiliki pengetahuan dan/atau pengalaman di bidang perbankan.

* Anggota dewan Komisaris hanya dapat merangkap jabatan:
a) Sebagai anggota dewan

Komisaris sebanyak-banyaknya

pada satu bank lain atau Bank

Perkreditan Rakyat; atau

b) Sebagai anggota dewan

Komisaris, Direksi atau Pejabat

Eksekutif yang memerlukan tanggung jawab penuh sebanyakbanyaknya pada dua perusahaan lain bukan bank atau bukan Bank Perkreditan rakyat.

* Mayoritas anggota dewan Komisaris dilarang memiliki hubungan keluarga sampai dengan derajat kedua termasuk suami/istri, menantu, dan ipar dengan anggota dewan Komisaris lain.

4. Dalam Pasal 22:

* Direksi Bank sekurang-kurangnya berjumlah tiga orang.
Mayoritas dari anggota Direksi wajib berpengalaman dalam operasional bank sekurangkurangnya 5 tahun sebagai Pejabat Eksekutif pada Bank.

5. Dalam Pasal 23:

* Mayoritas anggota Direksi dilarang memiliki hubungan keluarga sampai dengan derajat kedua termasuk suami/istri, keponakan, menantu, ipar, dan besan dengan anggota Direksi lain atau anggota dewan Komisaris;

* Anggota Direksi dilarang merangkap jabatan sebagai anggota dewan Komisaris, Direksi atau Pejabat Eksekutif pada lembaga perbankan, perusahaan atau lembaga lain;

* Di antara anggota-anggota Direksi dilarang secara sendiri-sendiri atau bersama-sama memiliki saham melebihi 25\% dari modal disetor pada suatu perusahaan lain;

* Direksi Bank dilarang memberikan kuasa umum kepada pihak lain yang mengakibatkan pengalihan tugas dan wewenang tanpa batas;

6. Persetujuan Bank Indonesia

Anggota Komisaris Bank harus mendapat persetujuan dari Pimpinan Bank Indonesia.Hal ini dijabarkan dalam Pasal 24.

* Calon anggota dewan Komisaris atau Direksi wajib memperoleh persetujuan dari Bank Indonesia sebelum diangkat dan menduduki jabatannya;

* Permohonan untuk memperoleh persetujuan sebagaimana dimaksud dalam ayat (1) wajib disampaikan oleh Direksi Bank kepada Direksi Bank Indonesia sebelum rapat umum pemegang saham atau rapat anggota yang mengesahkan pengangkatan dimaksud, disertai dengan dokumen sebagaimana dimaksud dalam Pasal 6 ayat (1) huruf c,Pasal 9 huruf h, I, j, k dan l; 
Persetujuan atau penolakan atas permohonan pengangkatan anggota dewan Komisaris atau Direksi diberikan selambat-lambatnya 15 hari sejak dokumen permohonan diterima secara lengkap;

* Dalam rangka memberikan persetujuan atau penolakan sebagaimana dimaksud dalam ayat

(3), Bank Indonesia melakukan:

1) Penelitian atas kelengkapan dan kebenaran dokumen sebagaiman dimaksud dalam ayat (2);

2) Wawancara terhadap calon anggota dewan Komisaris atau Direksi

* Laporan pengangkatan anggota dewan Komisaris atau Direksi wajib disampaikan oleh Direksi Bank kepada Direksi Bank Indonesia selambat-lambatnya 10 hari setelah pengangkatan dimaksud disahkan oleh rapat umum pemegang saham atau rapat anggota, disertai dengan notulen rapat umum pemegang saham atau notulen rapat anggota.

\section{g. Pimpinan Cabang}

Penggantian Pimpinan Cabang Bank wajib dilaporkan ke Pimpinan Bank Indonesia, hal ini dijabarkan dalam Pasal 25.Pengangkatan atau penggantian pemimpin Kantor Cabang wajib dilaporkan oleh Direksi Bank kepada Bank Indonesia selambatlambatnya 10 (sepuluh) hari setelah tanggal pengangkatan dan dilampiri dengan:

1) Surat pengangkatan dan pemberian kuasa sebagai pemimpin Kantor Cabang dan Direksi Bank;

2) Dokumen yang menyatakan identitas calon pemimpin Kantor Bank dengan persyaratan sebagaimana dimaksud dalam Pasal 6 ayat (1) huruf c angka 1, angka 2, dan angka 3, serta Pasal 9 huruf c angka 1dan angka 2.

\section{Pendirian Bank Perkreditan Rakyat (BPR)}

Pada pendirian BPR juga diperlukan izin usaha dari Bank Indonesia sebagaimana Bank Umum. Pada proses izin usaha dari Bank Indonesia diperlukan 2 tahap yaitu tahap persetujuan prinsip dan perolehan izin usaha. Selama salah satu atau kedua proses ini belum terpenuhi maka BPR tidak dapat melaksanakan kegiatan usaha apapun di bidang perbankan. Syarat-syarat untuk mendirikan BPR diatur dalam SK Direksi BI No.32/35/Kep/Dir, tentang Bank Perkreditan Rakyat tanggal 12 Mei 1999.

a. Syarat Umum, Modal, dan persetujuan Prinsip

1. Syarat Umum Pendirian BPR. Hal ini dijabarkan dalam Pasal 3:

a) BPR hanya dapat didirikan dan melakukan kegiatan usaha dengan izin Direksi Bank Indonesia

b) BPR hanya dapat didirikan oleh:

1) Warga Negara Indonesia yang seluruh kepemilikannya oleh Warga Negara Indonesia;

2) Badan Hukum Indonesia yang seluruh kepemilikannya oleh Warga Negara Indonesia;

3) Pemerintah Daerah

4) Dua pihak atau lebih sebagaimana dimaksud dalam huruf $a$, huruf $b$, dan huruf $c$.

2. Modal BPR. Dalam Pasal 4 disebutkan:

a. Modal disetor untuk mendirikan BPR ditetapkan sekurangkurangnya sebesar:

1. Rp. 2.000.000.000 (Dua Milyar Rupiah) untuk BPR yang didirikan diwilayah Daerah Khusus Ibukota jakarta Raya dan Kabupaten/Kotamadya Tanggerang, Bekasi, dan Karawang; 
2. Rp. 1.000.000.000 (Satu Milyar Rupiah) untuk BPR yang didirikan di wilayah ibukota propinsi diluar wilayah tersebut pada huruf a;

3. Rp. 500.000.000 (lim ratus juta rupiah) untuk BPR yang didirikan di luar wilayah tersebut pada huruf a dan huruf $b$.

b. Modal disetor bagi BPR yang berbentuk hukum Koperasi adalah simpanan pokok, simpanan wajib, dan hibah sebagaimana diatur dalam undang-undang tentang perkoperasian;

c. Bagian dari modal disetor BPR yang digunakan untuk modal kerja sekurang-kurangnya berjumlah $50 \%$ (lima puluh perseratus)

3. Persetujuan Prinsip.

Masalah ini dijabarkan dalam Pasal 6 sebagai berikut: Permohonan untuk mendapatkan persetujuan prinsip sebagaimana dimaksud dalam Pasal 5 huruf a diajukan oleh sekurangkurangnya oleh seorang calon pemilik kepada Direksi Bank Indonesia sesuai dengan format lampiran 1 dan wajib dilampiri dengan :

a. Rancangan akta pendirian badan hukum, termasuk rancangan anggaran dasar yang sekurangkurangnya memuat:

1) Nama dan tempat kedudukan

2) Kegiatan usaha sebagai BPR

3) Permodalan

4) Kepemilikan

5) Wewenang, tanggung jawab, dan masa jabatan dewan Komisaris dan Direksi;

b. Data kepemilikan berupa:

1) Daftar calon pemegang saham berikut rincian besarnya masingmasing kepemilikan saham bagi BPR yng berbentuk hukum
Perseroan Terbatas/Perusahaan Daerah

2) Daftar calon anggota berikut rincian jumlah simpanan pokok dan simpanan wajib, serta daftar hibah bagi BPR yang berbentuk hukum Koperasi

3) Daftar calon anggota dewan Komisaris dan Direksi disertai dengan:

a) Fotokopi KTP;

b) Riwayat hidup;

c) Surat pernyataan yang menyatakan tidak pernah melakukan tidakan tercela di bidang perbankan. Keuangan, dan usaha lainnya dan/atau tidak pernah dihukum karena terbukti melakukan tindak pidana kejahatan;

d) Surat keterangan atau bukti tertulis dari pihak sebelumnnyamengenai

pengalaman operasional dibidang perbankan bagi calon Direksi yang tidak berpengalaman;

e) Surat keterangan dari lembaga pendidikan perbankan yang pernah diikuti dan/atau bukti tertulis dari pihak Bank tempat bekerja sebelumya mengenai penglaman dibidang perbankan bagi calon anggota dewan komisaris

c. Rencana susunan organisasi;

d. Rencana kerja untuk tahun pertama yang sekurang-kurangnya memuat:

1) Hasil penelaahan mengenai peluang dasar dan potensi ekonomi;

2) Rencana kegiatan usaha yang mencakup penghimpunan dan penyaluran dana serta langkahlangkah kegiatan yang akan dilakukan dalam mewujudkan rencana dimaksud;

3) Rencana kebutuhan pegawai; 
4) Proyeksi arus kas bulanan selama 12 bulan yang dimulai sejak BPR melakukan kegiatan operasionalnya serta proyeksi neraca dan perhitungan laba rugi;

e. Bukti setoran modal sekurangkurangnya $30 \%$ dari modal disetor sebagaimana dimaksud dalam Pasal 4 ayat (1), dalam bentuk fotokopi Bilyet deposito pada Bank Umum di Indonesia dana atas nama "Direksi Bank Indonesia q.q salah seorang calon pemilik untuk pendirin BPR yang bersanngkutan" dengan mencantumkan keterangan bahwa pencairannya hanya dapat dilakukan setelah mendapat persetujuan tertulis dari Direksi Bank Indonesia

f. Surat pernyataan dai pemegang saham bagi BPR yang berbentuk hukum Perseroan Terbatas/Perusahaan Daerah atau dari calon anggota dari BPR yng berbentu hukum koperasi, bahwa setoran modal sebagaimana dimaksud dalam huruf f:

1) Tidak berasal dari pinjaman atau fasilitas pembiayaan dalam bentuk apapun dari bank dan/atau pihak lain di Indonesia;

2) Tidak berasal dari hasil kegiatan yang melnggar hukum.

\section{b. Daftar Calon Pemegang Saham}

Daftar calon pemegang saham atau calon anggota sebagaimana dimaksud dalam ayat (1) huruf b:

1. dalam hal perorangan wajib dilampiri dengan dokumen sebagaimana dimaksud dalam ayat (1) huruf c angnka 1, angka 2, dan angka 3;

2. dalam hal Badan Hukum wajib dilampiri dengan:

a) akta pendirian badan hukum termasuk anggaran dasar berikut perubahan-perubahan yang telah mendapat pengesahan dari instansi yang berwenang;

b) dokumen sebagimana dimaksud dalam ayat (1) huruf c angka 1, angka 2 dan angka 3 dari seluruh Dewan Komisaris dan Direksi badan hukum yang bersangkutan;

c) daftar pemegang saham berikut rincian besarnya masing-masing kepemilikan saham bagi badan hukum Perseroan Terbatas/Perusahaan Daerah, atau daftar anggota berikut rincian jumlah simpanan pokok, simpanan wajib serta daftar hibah bagi badan hukum koperasi;

d) laporan keuangan posisi akhir bulan sebelum tanggal pengajuan permhonan persetujuan prinsip;

e) laporan keuangan badan hukum yang diaudit oleh Akuntan Publik dengan posisi paling lama 6bulan sebelum tanggal pengajuan permohonan pengajuan prinsip, bagi badan hukum yang melakukan penyertaan sebesar Rp.1.000.000.000 atau lebih.

\section{c. Ijin Usaha Pendirian BPR}

Dalam pasal 9 disebutkan : Permohonan untuk mendapatkan izin usaha sebagaimana dimaksud dalam pasal 5 huruf $b$ diajukan oleh direksi BPR kepada direksi Bank Indonesia sesuai dengan format dalam lampiran 2 dan wajib dilampiri dengan:

1. akta pendirian badan hokum, termasuk anggaran dasar badan hukum yang telah disahkan oleh instansi yang berwenang;

2. data kepemilikan berupa :

a) daftar pemegang saham berikut rincian besarnya kepemilikan saham bagi BPR yang berbentuk badan hukum perseroan terbatas/perusahaan daerah;

b) daftar anggota berikut rincian jumlah simpanan pokok dan simpanan wajib serta daftar hibah bagi BPR yang berbentuk 
Hukum koperasi, yang masingmasing disertai dengan dokumen sebagaimana yang dimaksud pasal 6 ayat (2).

c) daftar susunan dewan Komisaris dan Direksi disertai dengan:

1) disertai pas foto terakhir ukuran $4 \times 4 \mathrm{~cm}$;

2) contoh tandatangan dan paraf;

3) dokumen sebagaimana dimaksud dalam pasal 6 ayat (1) huruf c.

3. susunan organisasi serta sistem dan prosedur kerja, termasuk personalia:

4. bukti pelunasan modal disetor sebagaimana dimaksud dalam pasal ayat (1), dalam bentuk fotokopi bilyet deposito pada Bank Umum di Indonesia dan atas nama "Direksi Bank Indonesia q.q. salah seorang pemilik BPR yang bersangkutan" dengan mencantumkan keterangan bahwa pencairannya hanya dapat dilakukan setelah mendapat persetujuan tertulis dari direksi bank Indonesia;

5. Bukti kesiapan operasional antara lain berupa:

a) Daftar aktiva tetap dan inventaris;

b) Bukti penguasaan gedung berupa bukti kepemilikan atau perjanjian sewa menyewa gedung kantor;

c) Foto gedung kantor dan tata letak ruangan;

d) Contoh formulir/warkat yang akan digunkan untuk operasional BPR;

e) Nomor Pokok Wajib Pajak (NPWP) dan Tanda Daftar Perusahaan (TDP).

f) Surat pernyataan dari pemegang saham bagi BPR yang berbentuk hukum

Perseroan Terbatas/Perusahaan Daerah atau dari anggota bagi BPR yang berbentuk hukum koperasi bahwa pelunasan modal disetor sebagaimana dimaksud dalam huruf c :

- Tidak berasal dari pinjaman atau fasilitas pembiayaan dalam bentuk apapun dari bank dan/atau pihak lain di Indonesia;

- Tidak berasal dari hasil kegiatan yang melanggar hukum.

6. Surat pernyataan tidak merangkap jabatan melebihi ketentuan sebagaimana dimaksud dalam pasal 20 ayat (3) dan ayat (4) bagi anggota dewan Komisaris;

7. Surat pernyataan tidak merangkap jabatan sebagaimana dimaksud dalam pasal 22 ayat (2) bagi anggota direksi;

8. Surat pernyataan dari anggota direksi bahwa yang bersangkutan bersedia menjadi direksi selama sekurang-kurangnya 3 tahun sejak BPR beroperasi dan tidak akan mengundurkan diri, kecuali mendapat persetujuan terlebih dahulu dari bank Indonesia;

9. Surat pernyataan dari anggota direksi bahwa yang bersangkutan tidak mempunyai hubungan keluarga sebagaimana dimaksud dalam pasal 22 ayat (1)

\section{d. Kepemilikan BPR}

Menurut pasal 13: Kepentingan BPR oleh Badan Hukum sebagaimana dimaksud dalam pasal 3 ayat (2) setinggi-tingginya sebesar modal sendiri bersih Badan Hukum yang bersangkutan; Modal sendiri bersih sebagaimana dimaksud ayat merupakan :

1) Penjumlahan dari modal disetor, cadangan, cadangan dan laba, dikurangi penyertaan dan kerugian, bagi badan hokum perseroan terbatas/perusahaan daerah; atau

2) Penjumlahan dari simpanan pokok, simpanan wajib, hibah, modal 
pernyertaan, dana cadangan dan sisa hasil usaha dikurangi penyertaan dan kerugian, bagi badan hukum koperasi.

Selanjutnya dalam pasal 15 disebutkan bahwa yang dapat menjadi pemilik BPR adalah pihak-pihak :

1. Tidak termasuk dalam daftar orang tercela dibidang perbankan sesuai dengan yang diterapkan oleh Bank Indonesia.

2. Menurut penilaian Bank Indonesia yang bersangkutan memiliki integritas, antara lain :

a) Memiliki akhlak dan moral yang baik;

b) Mematuhi peraturan-peraturan perundang-undangan yang berlaku;

c) Bersedia mengembangkan BPR yang sehat.

e. Perubahan modal dan Perubahan Pemilik Modal

1. Perubahan Modal

Hal ini dijabarkan dalam pasal 16 sebagai berikut :

a. Perubahan modal dasar bagi BPR yang berbentuk badan hokum perseroan terbatas/perusahaan daerah wajib dilaporkan oleh direksi BPR kepada bank Indonesia selambat-lambatnya 10 hari setelah tanggal persetujuan perubahan anggaran dasar dari instani yang berwnang dilampiri dengan:

1) Notulen rapat umum pemegang saham;

2) Perubahan anggaran dasar yang telah disetujui oleh rapat anggota.

b. Perubahan modal bagi BPR yang berbentuk hokum koperasi wajib dilaporkan oleh direksi BPR kepada bank Indonesia selambatlambatnya 10 hari setelah tanggal persetujuan perubahan anggaran dasar dilampiri dengan:
1) Notulen rapat umum pemegang saham;

2) Perubahan anggaran dasar yang telah disetujui oleh rapat anggota.

2. Perubahan Pemilik Modal Dalam pasal 17disebutkan :

a. Penggantian dan/atau penambahan pemilik BPR wajib terlebih dahulu memperoleh persetujuan dari Bank Indonesia;

b. Tatacara penggantian dan/atau penambahan pemilik BPR sebagaimana perundangundangan yang berlaku tentang merger, konsolidasi dan akuisi bank;

Selanjutnya dalam pasal 18 dikemukakan :

a. Perubahan komposisi kepemilikan yang tidak mengakibatkan penggantian dan/atau penambahan pemilik wajib dilaporkan oleh direksi BPR kepada Bank Indonesia selambatlambatnya 10 hari setelah perubahan dilakukan;

b. Laporan perubahan komposisi sebagaimana dimaksud dalam ayat (1) yang diakibatkan adanya penambahan modal disetor wajib dilampiri dengan:

1) Bukti penyetoran;

2) Notulen rapat umum pemegang saham/rapat anggota;

3) Surat pernytaan dari pemegang saham sebagaimana dimaksud dalam pasal 9 huruf g;

4) Data kepemilikan sebagaimana dimaksud dalam pasa 9 huruf b.

c. Laporan perubahan komposisi kepemilikan sebagaimana dimaksud dalam ayat (1) yang tidak mengubah modal disetor wajib dilampiri dengan dokumen sebagaimana dimaksud dalam ayat (2) huruf b, huruf c, huruf d; 


\section{f. Anggota Komisaris dan Direksi}

1. Anggota dewan komisaris dan direksi wajib memenuhi persyaratan sebagai berikut yang dalam pasal 19 disebutkan :

a) Tidak termasuk dalam daftar oang tercela dibidang perbankan sesuai dengan yang ditetapkan oleh bank Indonesia

b) Menurut penilaian bank Indonesia yang bersangkutan memiliki integritas, antara lain :

1) Memiliki akhlak dan moral yang baik;

2) Mematuhi peraturan perundang-undangan yang berlaku;

3) Bersedia mengembangkan dan melakuan kegiatan ussaha BPR secara sehat.

2. Jumlah anggota dewan Komisaris dan Direksi sekurang-kurangnya 1 orang;

a) Anggota dewan Komisaris sebagaimana dimaksud dalam ayat 1 wajib memiliki pengetahuan dan/atau pengalaman di bidang perbankan;

b) Anggota dewan komisaris BPR dapat merangkap jabatan sebagai komisaris sebanyak-banyaknya pada 3 BPR dan/atau BPR berdasarkan prinsip syariah;

c) Komisaris BPR dilarang menjabat sebagai anggota direksi pada bank umum.

3. Jumlah anggota direksi BPR sekurang-kurangnya 2 orang, Pasa 21:

a) Anggota direksi sekurangkurangnya berpendidikan formal setingkat Diploma II atau sarjana muda;

b) Sekurang-kurangnya $50 \%$ dari anggota direksi wajib berpengetahuan dalam operasional bank sekurangkurangnya 2 tahun sebagi pejabat di bidang pendanaan dan/atau perkreditan.

4. Syarat Menjadi Anggota Direksi

a) Anggota direksi dilarang mempunyai hubungan keluarga dengan :

1) Anggota direksi lainnya dalam hubungan sebagai orangtua termasuk mertua, anak termasuk menantu, saudara kandung termasuk hubungan sebagai orangtua, anak dan suami/istri;

2) Dewan komisaris dalam hubungan sebagai orang tua, anak dan suami/istri.

b) Anggota direksi BPR dilarang merangkap jabatan sebagai anggota direksi atau pejabat eksekutif pada lembaga perbankan, perusahaan atau lembaga lain;

c) Direksi BPR dilarang memberikan kuasa hokum kepada pihak lain yang mengakibatkan pengalihan tugas dan wewenang tanpa batas.

5. Penggantian Anggota dalam Pasal 23disebutkan:

a) Dalam hal terjadi penggantian anggota dewan komisaris dan/atau direksi, calon pengganti jabatan tersebut wajib memperoleh persetujuan dari direksi bank Indonesia sebelum diangkat dan menduduki jabatannya;

b) Permohonan untuk memperoleh persetujuan sebagaimana dimaksud dalam ayat (1) wajib disampaikan oleh direksi BPR kepada Bank Indonesia sebelum rapat umum pemegang saham atau rapat anggota yang mengesahkan pengangkatan dimaksud, disertai dengan dokumen sebagaimana dimaksud dalam pasal 9 huruf $c$, huruf $h$, huruf I dan huruf k; 
c) Persetujuan atau penolakan atas permodalan pengangkatan anggota dewan komisaris dan direksi diberikan selambatlambatnya 15 hari setelah dokumen permohonan diterima secara lengkap;

d) Dalam rangka memberikan persetujuan atau penolakan sebagaimana dimaksud dalam ayat (3), Bank Indonesia melakukan :

1. Penelitian atas kelengkapan dan kebenaran dokumen sebagaiimana yang dmaksud dalam ayat (2);

2. Wawancara terhadap calon anggota dewan komisaris dan direksi.

e) Laporan pengangkatan anggota dewan komisaris dan/atau direksi wajib disampaikan oleh direksi BPR kepada bank Indonesia selambat-lambatnya 10 hari setelah pengangkatan dimaksud disahkan oleh rapat umum pemegang saham atau rapat anggota sesuai dengan format dalam lampiran 5, disertai notulen rapat umum pemegang saham atau rapat anggota.

\section{g. Peningkatan Status BPR}

BPR dapat ditingkatkan statusnya menjadi Bank Umum. Persyaratannya adalah BPR tersebut harus memiliki tingkat permodalan, yang selama 12 bulan terakhir atau sekurang-kurangnya 10 bulan terakhir tergolong sehat dan selebihnya cukup sehat. BPR tersebut juga harus memenuhi persyaratan modal disetor untuk menjadi Bank Umum dan memenuhi ketentuan Direksi dan dewan Komisaris sebagaimana yang dipersyaratkan dalam Bank Umum.

\section{KESIMPULAN DAN IMPLIKASI}

Setiap pihak yang melakukan kegiatan menghimpun dana dari masyarakat dalam bentuk simpanan wajib terlebih dahulu memperoleh izin usaha sebagai Bank Umum atau Bank Perkreditan Rakyat dari Pimpinan Bank Indonesia, kecuali apabila kegiatan menghimpun dana dari masyarakat dimaksud diatur dengan Undangundang tersendiri (Pasal 16 ayat 1) Pasal 16 ayat 2: Untuk memperoleh izin usaha Bank Umum dan Bank Perkreditan Rakyat sebagaimana dimaksud dalam ayat (1), wajib dipenuhi persyaratan sekurangkurangnya tentang

1. Susunan organisasi dan kepengurusan :

2. Permodalan.

3. Kepemilikan.

4. Keahlian di bidang Perbankan.

5. Kelayakan rencana kerja.

6. Pasal 16 ayat 3: Persyaratan dan tata cara perizinan bank sebagaimana dimaksud dalam ayat (2) ditetapkan oleh BankIndonesia.

Dalam pendirian bank juga dibutuhkan beberapa syarat penting untuk mendapat persetujuan mendirikan bank. Dan banyak diatur oleh perundang-undangan, mulai dari kepemilikan, perizinan, sampai dengan susunan pengurus bank. Pendirian bank umum harus mengikuti syarat dan ketentuan dari pemerintah mulai dari persetujuan , modal, dewan komisaris dll agar dalam pengawasannya nanti tidak sulit dan dalam pelaksanaannya dapat sesuai dengan tujuan dari bank tersebut menghasilkan banyak manfaat bagi masyarakat. Selain bank umum, bank perkreditan rakyat pun dalam pendiriannya harus mengikuti prosedur yang sudah ditetapkan agar tetap mencapai tujuan. Dengan adanya berbagai ketentuan tersebut diharapkan 
dapat menghasilkan bank yang bermanfaat sesuai perundang-undangan

\section{DAFTAR PUSTAKA}

Hadisoewito, Selamat. 1987. DasarDasar Perbankan Indonesia. Jakarta: UPN veteran

Hasan, Nurul Ichsan . 2014 . Pengantar Perbankan . Jakarta: Gaung Persada

Judiseno, Rimsky K. 2005. Sistem Moneter dan Perbankan di Indonesia. Jakarta : PT.Gramedia Pustaka Utama.

Kasmir, S.E. M.M. 2011. Bank dan Lembaga Keuangan Lainya. Jakarta: Rajawali Pers

Kasmir. , 2003. Manajemen Perbankan. Jakarta: Rajawali Pers
Khan. Tariqullah . 2008 . Regulasi \& Pengawasan Bank Syariah . Jakarta Timur

Latumaerissa, Julius R. 1999. Mengenal Aspek-Aspek Operasi Bank Umum. Jakarta: Bumi Aksara.

Rahardja, Prathama. 1997.Uang dan Perbankan, Cetakan Ketiga, Jakarta : PT. Rineka Cipta

Riyanto, Bambang. 2001. Dasar-dasar Pembelanjaan Perusahaan. Yogyakarta:BPFE.

Siamat, Dahlan. Manajemen Lembaga Keuangan Kebijakan Moneter dan Perbankan.

Sinungan, Muchdarsyah. 1997. Manajemen Dana Bank. Jakarta:Bumi Aksara.

Gandapradja, Permadi, 2004. Dasar dan Prinsip Pengawasan Bank, Jakarta:PT.Gramedia Pustaka Utama. 